\title{
Kepemimpinan Kepala Sekolah dalam Menghadapi Era Revolusi Industri 4.0 : Perspektif Manajemen Pendidikan
}

\author{
Lilis Kholifatul Jannah \\ Universitas Muhammadiyah Sidoarjo \\ liliskholifatul@gmail.com
}

\begin{abstract}
In the industrial revolution 4.0 eras, the role of education has undergone the various changes; one of them is the headmaster role and leadership which should adapt to the requirements of the revolution. This research has a purpose to find out the headmaster leadership style deal with the industrial revolution 4.0 eras in the perspective of education management. It uses qualitative method with phenomenology approach. Its data collection techniques are observation, interview, and research documentation. Within, the interviewees consist of 6 headmaster and 1 school supervisor of the private school in Surabaya. The result shows that the headmaster leadership style transforms to be democratic as the result of the changing. Also, in the industrial revolution 4.0 eras; the headmaster knowledge and skills need to be strengthened, especially in the technology and entrepreneurship skills.
\end{abstract}

Keywords: Headmaster, Leader, Revolution, Education

\begin{abstract}
Abstrak: Peran pendidikan di era revolusi industri 4.0, bertransformasi mengalami berbagai perubahan, salah satunya adalah peran dan kepemimpinan kepala sekolah diharuskan menyesuaikan dengan tuntutan era revolusi industri 4.0. Tujuan penelitian ini yaitu untuk mengetahui gaya kepemimpinan kepala sekolah dalam menghadapi era revolusi industry 4.0 dalam perspektif management Pendidikan. Penelitian ini menggunakan metode penelitian kualitatif dengan pendekatan fenomenologi. Teknik pengumpulan data menggunakan observasi, wawancara, dan dokumentasi penelitian. Sedangkan narasumber penelitian yaitu berjumlah 6 kepala sekolah dan 1 pengawas di sekolah swasta di Surabaya. Hasil penelitian menggambarkan bahwa gaya kepemimpinan kepala sekolah yang demokratis mengikuti perubahan, berbagai pengetahuan serta keterampilan kepala sekolah di era revolusi industry 4.0 perlu untuk diperkuat terutama dalam keterampilan menggunakan teknologi dan kompetensi dalam wirausaha.
\end{abstract}

Kata Kunci : Kepala Sekolah, Pemimpin, Revolusi, Pendidikan

Islamika : Jurnal Keislaman dan Ilmu Pendidikan

Volume 2, Nomor 1, Januari 2020; 129-139

https:// ejournal.stitpn.ac.id/index.php/islamika 


\section{PENDAHULUAN}

Kehidupan di era revolusi industri 4.0 menjadi sebuah tantangan dalam dunia pendidikan. Dengan keberadaan era revolusi industri 4.0 bisa ditandai dengan berbagai kemajuan di bidang online. Misalnya mobile, smartphone, internet komputerisasi data kecerdasan buatan, dan robotisasi. Dalam lembaga pendidikan yang dituntut bukan hanya kemajuan ilmu pengetahuan dan teknologi, namun pendidikan harus bisa mencetak sumber daya manusia yang berkualitas yang dapat bersaing dalam tataran lokal, nasional, maupun internasional. Salah satu upaya guna meningkatkan kualitas pendidikan di era revolusi industri 4.0, kepala sekolah menjadi komponen yang sangat penting untuk merealisasikannya kepemimpinan dalam lembaga pendidikan.

Lembaga pendidikan mempunyai peranan yang sangat penting dalam membangkitkan pendidikan nasional yang berkualitas dan mampu bersaing di zaman yang semakin modern ini. Jika sebuah lembaga pendidikan maju maka pendidikan di Indonesia juga akan maju. Dalam hal ini tidak akan pernah lepas dari peran seorang kepala sekolah. Kepala sekolah sebagai imam, pemimpin, pemangku kepentingan di sekolah.

Sebagai motor utama penggerak bagi lembaga pendidikan, kepala sekolah harus bekerja secara optimal. Karena baik dan buruknya sebuah lembaga atau organisasi dapat dipengaruhi dari gaya kepemimpinan seorang kepala sekolah.

Kepala sekolah juga akan menginginkan sebuah pendidikan yang berkualitas. Maka kepala sekolah juga harus memperhatikan sumber daya manusia (SDM) yang ada di lembaga tersebut. Dalam konteks bangsa Indonesia, peningkatan mutu pendidikan merupakan sasaran pembangunan di bidang pendidikan nasional dan merupakan bagian integral dari upaya peningkatan kualitas manusia Indonesia secara menyeluruh. ${ }^{1}$

Kepala sekolah merupakan jabatan tertinggi dalam sebuah organisasi sekolah. Selain sebagai pemimpin kepala sekolah merupakan penanggungjawab kegiatan yang dilaksanakan dalam sekolah tersebut. Kepala sekolah memiliki tuntutan yang sangat

${ }^{1}$ E. Mulyasa, Menjadi Kepala Sekolah Profesional dalam Menyukseskan MBS dan KBK (Bandung: PT. Remaja Rosdakarya, 2005), h. 31. 
tinggi untuk memimpin seluruh komponen di sekolah, baik siswa, guru, dan karyawan. Kepala sekolah sebagai pemimpin dan manajer sekolah memiliki peran yang sangat penting dalam mengahadapi tantangan revolusi industri 4.0, oleh karenanya kepala sekolah dituntut untuk memiliki jiwa kewirausahaa, pandai membuka jaringan dan kemitraan dengan berbagai pemangku kepentingan (stakeholder), seperti komite sekolah, dunia usaha dan industri (DUDI) dan Lembaga Swadaya Masyarakat (LSM) sebagai bentuk sinergi dalam melaksanakan program tersebut. Para guru juga harus mulai merubah sistem mendidik dari konvensional/tradisional menuju modern dengan dibekali model-model pembelajaran abad 21. Guru saat ini harus menjadi guru era digital karena siswa yang harus dihadapi saat ini merupakan generasi digital yang sangat tergantung dengan teknologi.

Tantangan terbesar dalam era revolusi industri 4.0 adalah bagaimana kita bisa bertahan dalam menghadapi era tersebut. Kepala sekolah harus memiliki keterampilan khusus agar dapat tetap bertahan dalam arus globalisasi dan memajukan sekolah yang dipimpinnya. Arus globalisasi dan kemajuan pembelajaran abad 21 harus disikapi dengan baik. Salah satu contoh yaitu perubahan pola pikir anak zaman sekarang juga menjadi tantangan seorang kepala sekolah dan staf-staf nya agar mampu mendapatkan solusi terbaik dalam menanggulanginya Melihat berbagai permasalahan di dunia pendidikan dengan adanya revolusi industri 4.0 dan pembelajaran abad 21, kepala sekolah diharapkan berinovasi dan memiliki ide-ide cemerlang agar mampu mengerti mengenai peluang yang terjadi di revolusi industri sehingga dapat memunculkan solusi yang tepat bagi kepala sekolah dalam mengahdapi era revolusi industri. Tantangan kepemimpinan kepala sekolah dalam era revolusi industri juga diharapkan akan menimbulkan solusi yang tepat bagi kepala sekolah dalam menjalankan tugas dan fungsinya di era revolusi industri 4.0 dan pembelajaran abad ke-21

Saat ini semua kepala sekolah dituntut profesional memiliki berbagai kompetensi, sebagaimana yang diatur dalam Peraturan Menteri Pendidikan Nasional Nomor 13 Tahun 2007 tentang Standar Kepala Sekolah, bahwa kepala sekolah memiliki kompetensi-kompetensi yaitu: kepribadian, supervisi, manajerial, 
kewirausahaan, dan kompetensi sosial. Gaya kepemimpin kepala sekolah menurut Damsar dalam buku Sosiologi Pendidikan yaitu kepemimpinan autokratik, laisser faire, dan demokratik. Sedangkan menurut Haris gaya kepemimpinan kepala sekolah dibagi menjadi kepemimpinan demokratis, otoriter, kharismatik (charismatic leadership), kepemimpinan kebapakkan (paternalistic leadership), kepemimpinan ahli (expert leadership, kepemimpinan yang bebas (laissez faire leadership). Berbagai gaya kepemimpinan kepala sekolah yang beragam tersebut memiliki kelebihan dan kekurangan masing-masing, namun yang harus diperhatikan ialah implementasi gaya kepemimpinan kepala sekolah harus disesuaikan dengan keadaan yang terjadi pada lembaga pendidikan saat ini. Setiap kepala sekolah diharapkan memiliki gaya kepemimpinan yang ideal disesuaikan dengan kondisi serta tuntutan zaman. Namun yang menjadi Permasalahan tidak semua kepala sekolah memiliki kemampuan untuk dapat menyesuaikan diri dengan tuntutan perubahan, ditambah lagi dengan kurangnya pengetahuan kepala sekolah terhadap tranformasi kepemimpinan kepala sekolah di abad 21.

\section{METODE PENELITIAN}

Metode penelitian yang digunakan dalam artikel ini yaitu penelitian kualitatif dengan pendekatan fenomenologi, peneliti menganalisis fenomena perubahan yang terjadi dalam dunia pendidikan, sehingga melibatkan kepala sekolah untuk beradaptasi dengan perubahan tuntutan dunia pendidikan di era revolusi industri 4.0. Narasumber dalam penelitian ini berjumlah 6 orang terdiri dari 5 informan dan satu kunci yaitu Kepala Pengawas di sekolah swasta di Surabaya.

Adapun teknik pengambilan data dilakukan dengan cara observasi, wawancara, dan dokumentasi. Semua data terkait kepemimpinan kepala sekolah dikumpulkan menjadi satu dan dianalisis secara deskripsi. Sebagaimana yang disampaikan oleh Miles dan Huberman "kegiatan analisis kualitatif terdiri dari tiga alur yaitu reduksi data, penyajian data, dan penarikan kesimpulan atau verifikasi”. Analisis data dilakukan secara bersamaan selama pengumpulan data berlangsung sampai sesudah pengumpulan data. Berdasarkan analisis kualitatif peneliti dapat 
menarik hasil penelitian berdasarkan data yang ada terkait dengan kepemimpinan kepala sekolah dalam menghadapi era revolusi industri 4.0.

\section{HASIL DAN PEMBAHASAN}

Berdasarkan temuan hasil penelitian menunjukkan adanya gaya kepemimpinan kepala sekolah sangat beragam, tergantung pribadi masing-masing dalam memimpin lembaganya. Terdapat kepala sekolah yang sangat otoriter kepada bawahannya. Berikut transkrip wawancara dengan narasumber: "Kepemimpinan saya sangat tegas dikarenakan guru jika tidak diberikan ketegasan maka dia tidak akan disiplin, semua guru taat pada perintah saya sebagai kepala sekolah dan terbukti hasil pekerjaan dilakukan dengan baike" (Wawancara dengan narasumber CH, pada tanggal 1 Desember 2019). Berdasarkan hasil kutipan wawancara tersebut, menunjukkan bahwa kepemimpinan yang dilakukan oleh narasumber merupakan gaya kepemimpinan yang otoriter. Gaya kepemimpinan kepala sekolah yang otoriter cenderung menggunakan kekuasaannya. Kepemimpinan yang otoriter dapat dikaji dalam teori Karl Marx mengenai konflik, melihat kepemimpinan otoriter akan memiliki kekuasaan yang mutlak berada ditangannya, sehingga hal tersebut sangat rentan menimbulkan konflik. Kepala sekolah otoriter sangat mendominasi kepemimpinannya, tegas, pemimpin dengan gaya ini mengontrol secara ketat kinerja dari bawahannya. Kepala sekolah yang bersifat otoriter tidak memberikan ruang bagi guru, staf sekolah, serta seluruh warga sekolah untuk mengemukakan pendapat sehingga mereka tidak diikutsertakan dalam mengambil keputusan. Pada akhirnya dapat menambah masalah di sekolah seperti kebijakan sekolah yang tidak tepat karena tidak dimusyawarahkan, adanya pihakpihak yang dirugikan atau didiskriminasikan, karena kekuasaan kepala sekolah yang sangat tinggi maka beresiko terjadi penyimpangan korupsi dana sekolah.

Gaya kepemimpinan kharismatik bercirikan kepada kepribadian dari pemimpin yang istimewa memiliki kewibawaan dan daya tarik sehingga dipatuhi oleh bawahannya, pemimpin yang memiliki kekuasaan yang kuat serta dipercaya bawahannya, pemimpin yangkharismatik memiliki kemampuan mempengaruhi bawahannya dengan gaya kepemimpinannya. Berdasarkan penelitian, gaya kepemimpinan kharismatik jarang ditemukan karena keistimewaan tersebut tidak bisa dimiliki oleh sembarangan orang. Adapun gaya kepemimpinan kebapakan merupakan 
gaya pemimpin yang bersifat mengayomi, melindungi, serta menolong bawahannya. Seseorang pemimpin paternalistis akan selalu menganggap bawahannya sebagai manusia yang tidak dewasa, oleh karena itu pigur kepala sekolah kebapakkan ini selalu ingin didengar serta mengetahui segalanya, sehingga jarang memberikan kesempatan kepada bawahannya dalam memberikan berbagai perubahan, inovasi atau kreasi.

Gaya kepemimpinan ahli merupakan kepemimpinan yang berdasarkan keahlian atau keterampilan yang dimiliki, pemimpin yang profesional diperoleh melalui jenjang pendidikan maupun pengalaman. Jika dilihat dari lamanya pengalaman narasumber dalam menjabat sebagai kepala sekolah hanya beberapa orang saja yang lama menjabat sebagai kepala sekolah ,rata-rata menjadi kepala sekolah selama 3-10 tahun dan pendidikan rata-rata sarjana.

Musyawarah memberikan banyak peluang partisipasi bagi seluruh warga sekolah untuk menyalurkan berbagai aspirasi, kritik, dan saran yang dapat membangun bagi kemajuan sekolah. Kepala sekolah demokratis senantiasa merangkul dan mengayomi bawahannya tanpa membeda-bedakan satu dengan yang lainnya. Kepala sekolah demokratis dapat menyelesaikan berbagai permasalahan yang terjadi di sekolah dengan bijaksana dan diputuskan bersama-sama. Berbagai kepemimpinan tersebut harus disesuaikan dengan kondisituntutan masyarakat saat ini. Kepemimpinan ideal lahir dari kompetensi yang dimiliki oleh kepala sekolah dalam memimpin sekolahnya. Kompetensi kepala sekolah telah termaktub dalam Peraturan Menteri Pendidikan Nasional Nomor 13 Tahun 2007 tentang Standar Kepala Sekolah,bahwa kepala sekolah memiliki kompetensi-kompetensi yaitu: kepribadian, supervisi, manajerial, kewirausahaan, dan kompetensi sosial.

Kompetensi kepribadian kepala sekolah yang peneliti temukan meliputi sebagai berikut: kepala sekolah memiliki akhlak mulia; amanah dalam mengemban tugas; disiplin, integritas yang tinggi; terbuka terhadap pembaharuan menerima kritik dan saran; keinginan yang kuat dalam penembangan diri; memiliki minat dan bakat sebagai kepala sekolah. Kepala sekolah menjadi panutan bagi guru, siswa, dan seluruh warga sekolah sehingga kompetensi kepribadian ini sangat penting dimiliki kepala 
sekolah. Dokumentasi kepribadian kepala sekolah yang dapat membuat suasana sekolah lebih baik. Kompetensi kepribadian yang dimiliki kepala sekolah.

Menurut Purwanto kepala sekolah yang jujur adil dan dapat dipercaya; rendah hati dan sederhana; percaya pada diri sendiri; sabar dan emosinya stabil; suka menolong; motivator; serta memiliki keahlian dalam jabatan sebagai kepala sekolah. Sedangkan Toharudin \& Ghufroni menjelaskan bahwa kepala sekolah memiliki kedisiplin yang tinggi dalam bekerja, bertanggung jawab, kekeluargaan, dan menerapkan budaya: senyum, sapa, salam bagi guru dan siswa.

Gaya kepemimpinan yang tepat dilakukan saat ini yaitu kepala sekolah yang memiliki visi misi ke depan, percaya diri, mampu mengkomunikasikan ide, dapat diteladani, mempunyai idealisme, inspirasi, kemampuan mempengaruhi dan mampu menghargai perbedaan untuk dirubah menjadi suatu kekuatan bersama. Berdasarkan berbagai kepribadian kepala sekolah yang telah dipaparkan, menjadi sebuah keistimewaan sebagai seorang pemimpin yang menjadi panutan untuk generasi penerus bangsa. Kemampuan yang penting yang harus dimiliki kepala sekolah yaitu kemampuan manajerial, adapun kemampuan tersebut meliputi: kepala sekolah mampu memimpin sekolah; menyusun rencana program sekolah, kurikulum, serta berbagai kebijakan sekolah; mengelola guru, staf, peserta didik, serta seluruh warga sekolah; menjalin hubungan baik dengan wali murid, komite sekolah, serta masyarakat; mengelola sarana dan prasarana di sekolah; mengelola mengelola keuangan secara jujurtransparan, dan terpercaya; serta dapat mamanfaatkan kemajuan teknologi di sekolah.

Pada era revolusi industry 4.0 kepala sekolah dituntut untuk memiliki kompetensi kewirausahaan, sehingga dapat melahirkan berbagai kreativitas dan inovasi dari guru maupun siswa di sekolah. Berdasarkan hasil transkrip wawancara dengan narsumber, peneliti mendapatkan temuan bahwa kemampuan kewirausahaan sangat minim dilakukan di sekolah. "Saya belum memiliki kewirausahaan di sekolah hal tersebut dikarenakan rata-rata peserta didik berdasarkan dari latar belakang ekonomi yang kurang memadai, sehingga untuk menerapkan sekolah kewirausahaan cukup sulit dilakukan. Namun kedepannya saya akan membuat koperasi untuk siswa yang di dalamnya terdapat warung kejujuran”. (Wawancara dengan narasumber CH, pada tanggal 2 Desember 2019). 
Berdasarkan kutipan tersebut, maka dapat disimpulkan bahwa kepala sekolah belum dapatmengembangkan kemampuan kewirausahaan di sekolahnya. Oleh karena itu, butuh bantuan dari berbagai pihak untuk dapat mengeksplor berbagai potensi yang dimiliki sekolah, kebanyakan kepala sekolah tidak mengetahui cara memulainya, tidak memiliki modal, kesulitan mencari sumber daya yang berkompetensi di bidang wirausaha. Pihak sekolah dapat menjalin bekerjasama dengan masyarakat sekitar yang memiliki Usaha Kecil dan Menengah (UKM) untuk berkolaborasi membentuk usaha sekolah, sehingga diharapkan dengan kemampuan kewirausahaan yang dimiliki kepala sekolah dapat menjadikan sekolah lebih unggul dan mandiri.

Kompetensi kepala sekolah selanjutnya terkait dengan kompetensi untuk melaksanakan supervisi pendidikan di sekolah. Berdasarkan hasil wawancara dengan pengawas kepala sekolah Swasta sebagai berikut: "Sebagai pengawas saya selalu memberitahukan kepada kepala sekolah untuk dapat melakukan supervisi secara mandiri dan berkala, dalam rangka meningkatkan mutu pendidikan di sekolah. Selama ini para kepala sekolah beranggapan bahwa tugas supervisi merupakan tugas pengawas, padahal kegiatan supervisi merupakan bagian dari tugas kepala sekolah. Berbagai kemampuan yang harus dimiliki kepala sekolah perlu ditingkatkan sehingga mereka dapat meningkatkan kualitas kepemimpinannya." (Wawancara dengan narasumber BM, pada tanggal 9 Desember 2019).

Kepala sekolah memainkan peran penting dalam melakukan monitoring pendidikan, hal tersebut selaras dengan hasil penelitian yang dilakukan Fitrah, kepala sekolah memiliki peran penting dalam melakukan berbagai upaya untuk meningkatkan kualitas pendidikan dengan melakukan monitoring, evaluasi terhadap program yang berorientasi pada visi misi sekolah Kompetensi terakhir yang harus dimiliki kepala sekolah yaitu kompetensi sosial yang dapat dilihat dari kerjasama antara kepala sekolah dengan masyarakat, sekolah dituntut untuk dapat berpartisipasi dalam kegiatan sosial dan memiliki kepekaan sosial di lingkungan sekitar.

Penelitian terkait kesiapan kepala sekolah dalam era revolusi industri 4.0 pernah dilakukan oleh Sugiarto, hasil penelitian menunjukkan bahwa perlu adanya kesiapan profesionalisme kepala sekolah, kesiapan kepala sekolah dalam menghadapi tantangan, serta kesiapan dalam memberikan solusi terhadap masalah tantangan kepemimpinan kepala sekolah di era revolusi industry 4.0. Kepemimpinan 
yang ideal adalah kepemimpinan yang mengikuti tuntutan revolusi industri 4.0, pemimpin yang mengikuti perkembangan teknologi untuk dapat mempengaruhi, mendorong, membimbing, mengarahkan, dan menggerakkan orang lain untuk melaksanakan dan mengembangkan pendidikan dan pengajaran di era revolusi industi 4.0 .

Menurut management Pendidikan, kepala sekolah harus menjadi agen perubahan dimana kepala sekolah harus mengikuti perubahan yang ada. Namun pesatnya kemajuan teknologi tetap saja harus diimbangi dengan kualitas sumber daya manusianya. Tugas penting kepala sekolah dalam memberikan bekal untuk meningkatkan keterampilan abad 21 bagi guru dan siswa dengan memiliki keterampilan komunikasi, kreativitas, kolaborasi, dan kritis dalam memecahkan masalah. Selain itu, siswa diharapkan dapat mengimbangi diri dari dampak negatif kemajuan zaman dengan melakukan kegiatan yang positif. Management melihat pendidikan sebagai miniatur dari masyarakat, oleh karena itu untuk menciptakan masyarakat yang berkualitas maka dimulai dari lembaga pendidikan. Menurut teori struktur fungsional masyarakat merupakan sistem sosial yang saling berkaitan terdapat sistem pendidikan, keluarga, masyarakat yang saling bersinergis mencapai keseimbangan dan keharmonisan.

Teori struktur fungsional memandang bahwa sekolah memiliki fungsi masingmasing sesuai dengan tugas dan tanggungjawabnya. Kepala sekolah dalam kacamata teori structural fungsional dapat menjalankan fungsinya dengan baik. Sehingga kepemimpinan kepala sekolah yang fungsional sangat menentukan kemajuan dari lembaga pendidikan yang dipimpinnya dan dapat memberikan manfaat bagi warga sekolah terutama bagi guru. Hasil penelitian menunjukkan bahwa kepemimpinan kepala sekolah dapat mempengaruhi kinerja dan motivasi guru. Oleh karena itu, tidak heran jika tonggak dari kemajuan pendidikan di tangan kepemimpinan kepala sekolah. Sebagai upaya untuk meningkatkan kompetensi yang dimiliki kepala sekolah, maka salah satunya dengan mengikuti kegiatan workshop tentang tugas dan kewajiban kepala sekolah yang dapat meningkatkan kualitas guru dan tenaga pendidik di sekolah yang dipimpinnya. Selain itu, para kepala sekolah juga dapat melanjutkan pendidikan yang lebih tinggi untuk memperbaharui keilmuan yang dimiliki, mengikuti 
berbagai pendidikan dan pelatihan, seminar, dan berbagai kegiatan yang mendukung untuk memberikan penguatan kepada kepala sekolah dalam kepemimpinannya.

\section{KESIMPULAN}

Gaya kepemimpinan kepala sekolah mengalami tranformasi mengikuti perubahan, gaya kepemimpinan kepala sekolah yang lebih cocok saat ini yaitu dengan kepemimpinan demokratis yang dapat merangkul guru, siswa, komite sekolah, wali murid, maupun masyarakat. Dalam kajian sosiologi pendidikan maka sekolah harus menjalankan fungsinya dengan baik sehingga kepemimpinan kepala sekolah dapat menjadi kemajuan lembaga pendidikan yang dipimpin. Menjadi kepala sekolah yang professional dituntut memiliki kompetensi kepribadian, manajerial, kewirausahaan, supervisi, dan kompetensi sosial. Keterampilan dalam menghadapi era revolusi industry 4.0 dapat dilihat dari kemampuan kepala sekolah dalam penggunaan teknologi dan kemampuan berwirausaha. Upaya yang dilakukan kepala sekolah untuk meningkatkan kemampuan diri yaitu dengan melanjutkan pendidikan, mengikuti berbagai pelatihan, seminar, workshop, dan berbagai kegiatan yang mendukung. Perlu adanya kolaborasi dari berbagai pihak terutama pemangku kebijakan agar kepala sekolah dapat menjadi pemimpin yang professional dan berkualitas.

\section{DAFTAR PUSTAKA}

Kemendikbud. Undang-Undang Nomor 20 Tahun 2003 Tentang Sistem Pendidikan Nasional (2003). Diambil dari http://kelembagaan.ristekdikti.go.id/wpcontent/uploads/2016/08/UU_no_2 0_th_2003.pdf (diakses 21 Desember 2019)

Menteri Pendidikan. Peraturan Menteri Pendidikan Nasional Nomor 13 Tahun 2007 (2007).

Nursyifa, A. (2019). Pembinaan Kepala Sekolah Dalam Upaya Meningkatkan Mutu Pendidikan. Jurnal Loyalitas Sosial, 1(1). Diambil dari http://openjournal.unpam.ac.id/index.php/JLS

Baihaqi, M. I. (2015). Pengaruh Gaya Kepemimpinan Kepala Sekolah dan Motivasi Kerja Terhadap Kinerja Guru. Kontruktivisme, 7(2), 97-106.

Ekosiswoyo, R. (2007). Kepemimpinan kepala sekolah yang efektif kunci pencapaian kualitas pendidikan. Jurnal Ilmu Pendidikan, 14(2), 76-82. 
Fitrah, M. (2017). Peran kepala sekolah dalam meningkatkan mutu pendidikan. Jurnal Penjamin Mutu, 3(1).

Wahab, J. A., Mohd Fuad, C. F., Ismail, H., \& Majid, S. (2014). Headmasters Transformational Leadership and Their Relationship with Teachers ' Job Satisfaction and Teachers' Commitments. International Education Studies, 7(13). https://doi.org/10.5539/ies.v7n13p40 (diakses 21 Desember 2019)

Sugiarto, A., \& Mastikasari, K. (2018). Pengaruh Kepemimpinan Transformasional Kepala Sekolah, Lingkungan Kerja, dan Budaya Sekolah Terhadap Kinerja Guru di SMA Kota Wates Dalam Menghadapi Revolusi Industri 4.0. In Prosiding Seminar Nasional FKIP. Yogyakarta: Universitas Sanata Dharma. Diambil dari http://usd.ac.id/snfkip2018 ((diakses 21 Desember 2019) 